\title{
Immune Dysfunction in Cystic Fibrosis
}

\author{
Yaqin $\mathrm{Xu}$ and Stefan Worgall \\ Weill Cornell Medical College, Department of Pediatrics, New York, NY,
}

USA

\section{Introduction}

Absence of the cystic fibrosis transmembrane regulator (CFTR) function leads to chronic lung disease characterized by inflammation and persistent infections. The mechanisms for the increased susceptibility of the respiratory tract for infections in CF are most likely complex and only partially understood. Most attention has been focused on the effect of the defective expression of CFTR in epithelial cells and submucosal gland cells and the increased susceptibility of the respiratory tract to infections was was mostly thought to be related to the abnormal chloride channel function (Welsh MJ, 2011, Ratjen F 2003). However, numerous studies over the past years have shown that the absence of CFTR affects the immune system and that dysfunctional immune responses contribute to pathological processes in the CF lung. In addition, it has become increasingly evident that the chloride channel dysfunction alone cannot completely explain the pathology of CF lung disease and that other pathways known to be regulated by CFTR play a role in the immune dysregulation in the CF lung (Mehta A 2008). This chapter reviews both soluble factors in the CF milieu that modify immune cell function and specific alterations in the cellular components of the innate and adaptive immune system that contribute to the impaired immune defense in CF lung disease.

\section{The role of immune responses in CF}

Innate host defenses are defective in CF. It is still not entirely clear how defective CFTR results in an impaired host response in the CF lung. Three general components comprise the innate and adaptive immune defenses in the respiratory tract: (1) the mucociliary escalator; (2) a humoral component of surfactant proteins, defensins, and other antimicrobial compounds; and (3) a cellular component that includes epithelial cells, neutrophils, macrophages, monocytes, dendritic cells, and lymphocytes.

\subsection{Abnormal humoral responses in CF}

The respiratory tract epithelium and the cells of the submucosal glands in the airways constitute a major part of the innate immune defense system of the lung that responds primarily to incoming pathogens with the release of various mediators. They are influenced and/or amplified in their responses by factors such as cytokines derived from neighboring inflammatory and immune cells (Bartlett J 2008). The defective chloride channel function in CF leads to alterations in the physical properties of the airway mucus and the composition of the airway surface liquid that are linked to impairment of innate defense mechanisms. These affect 
the shield of antimicrobial factors such as lysozyme, lactoferrin, defensins, and other antimicrobial peptides, as well as disturb the mechanical clearance of inhaled particles and pathogens by the mucociliary escalator. Table 1 summarizes the known alterations in soluble innate immune factors in the $\mathrm{CF}$ lung. One school of thought has pursued the concept that alterations in the chloride secretion and sodium hyperabsorption in the airways lead to the subsequent entrapment of pathogens that then lead to recruitment and activation of neutrophils and macrophages. This has also been supported by the lung phenotype of a mouse model with genetic over-expression of the sodium channel ENac that mimics CF with thick mucus and inflammation in the absence of infection (Mall MA 2010). Salt-sensitive antimicrobials such as defensins were initially thought to be defective in the human CF lung. However, as the exact concentrations of chloride and sodium in the airway liquid are still not entirely clear, and so the degree of impairment of these innate defense mechanisms in CF is not exactly known.

\begin{tabular}{|c|c|c|}
\hline Mediator & Abnormality & Reference \\
\hline Defensins & Impaired activity & $\begin{array}{l}\text { Goldman MJ et al. 1997, Bals R et al. } \\
2001\end{array}$ \\
\hline Surfactant proteins & Decreased or inactive & $\begin{array}{l}\text { Hartl D, Griese M 2006, Meyer KC et } \\
\text { al. 2000, Noah TL et al. } 2003\end{array}$ \\
\hline Antioxidants & $\begin{array}{l}\text { Reduced glutathione } \\
\text { availability in airways }\end{array}$ & $\begin{array}{l}\text { Gao L et al. 1999, Roum JH et al. 1993, } \\
\text { Day BJ 2005, Childers M et al. 2007, } \\
\text { Hudson VM } 2001\end{array}$ \\
\hline Opsonins & Proteolytic degradation & Eichler I et al. 1989 \\
\hline \multicolumn{3}{|l|}{ Cytokines } \\
\hline IFN- $\gamma^{1}$ & Decreased secretion & Moss RB et al.1996 and 2000 \\
\hline IL-12 & Increased secretion & Bonfield TL et al. 1995 \\
\hline IL- $4^{3}$ & Increased secretion & $\begin{array}{l}\text { Moss RB et al.1996 and 2000, Mueller C } \\
\text { et al.2010 }\end{array}$ \\
\hline IL-6 ${ }^{4}$ & Increased secretion & $\begin{array}{l}\text { Black HR et al. 1998, Becker MN et al. } \\
\text { 2004, Andersson C et al. 2007, } \\
\text { Vandivier RW et al. 2009, }\end{array}$ \\
\hline IL- $8^{5}$ & Increased secretion & $\begin{array}{l}\text { Bonfield TL et al. 1995, Black HR et al. } \\
\text { 1998, Becker MN et al. 2004, Vandivier } \\
\text { RW et al. 2009, }\end{array}$ \\
\hline IL-106 & Altered secretion & $\begin{array}{l}\text { Bonfield TL et al. 1995, Moss RB et al. } \\
1996 \text { and 2000, Armstrong DS et al. } \\
2005\end{array}$ \\
\hline IL-137 & Increased secretion & Mueller C et al.2010 \\
\hline IL-178 & Increased secretion & $\begin{array}{l}\text { McAllister F et al.2005, Tan HL et } \\
\text { al.2011 }\end{array}$ \\
\hline TNF- $\alpha^{9}$ & Increased secretion & $\begin{array}{l}\text { Bonfield TL et al. 1995, Andersson C et } \\
\text { al. 2007, }\end{array}$ \\
\hline \multicolumn{3}{|l|}{ Chemokines } \\
\hline MIP-1 $\beta^{10}$ & Increased secretion & Brennan S et al. 2009 \\
\hline MCP-1 ${ }^{11}$ & Increased secretion & Brennan S et al. 2009 \\
\hline
\end{tabular}

Notes: ${ }^{1}$ IFN- $\gamma$ ( interferon-gamma); ${ }^{2}$ IL-1 $\beta$ (interleukin-1 beta), ${ }^{3}$ IL-4 (interleukin-4), ${ }^{4}$ IL-6 (interleukin6), ${ }^{5}$ IL-8 (interleukin-8), ${ }^{6}$ IL-10 (interleukin-10), ${ }^{7}$ IL-13 (interleukin-13), 8 IL-17(interleukin-17), ${ }^{9}$ TNF- $\alpha$ ( tumor necrosis factor-alpha), ${ }^{10} \mathrm{MIP}-1 \beta$ (macrophage inflammatory protein-1 beta), ${ }^{11} \mathrm{MCP}-1$

(macrophage chemotactic protein-1)

Table 1. Altered humoral mediators in the respiratory tract in $\mathrm{CF}$ 


\subsubsection{Soluble mediators}

Numerous humoral factors that affect pulmonary innate immune response have been studied in the CF lung. These include the collectins and surfactant proteins (Hartl D 2006, Noah TL 2003, Meyer KC 2000), defensins (Goldman MJ 1997, Bals 2001), glutathione (Gao TJ 1999, Kogan I 2003, Roum JH 1993, Hudson VM 2001) and antiproteases such as secretory leukoprotease inhibitor (SLPI) and tissue inhibitor of metalloproteinase 1 (TIMP-1) (Gaggar 2007, Cantin AM 1991, Vandivier 2002). Initially, it was thought that defensins in the CF lung were impaired due to the altered salt concentration in the CF airway (Goldmann 1997). Subsequent studies showed the impairment of defensins is not only related to an altered salt concentration, but also to increased inflammation (Bals 2001, Chen CI 2004). The Levels of $\beta$ defensin were even found to be similar in bronchial brushings in CF and non CF patients (Dauletbaev N 2002). Surfactant proteins, besides their surface-tension regulating properties, also have immuno-modulatory and anti-inflammatory functions were shown to be degraded (Hartl D 2006, Noah TL 2003) and structurally altered in CF (Meyer KC 2000). Glutathione, a critical component of the antioxidant defense system in the lung, was found to be reduced in the CF lung (Roum JH 1993). Importantly, this seemed to be directly related to the function of CFTR as a channel for the transmembrane transport of glutathione (Gao 1999, Kogan 2003). As glutathione deficiency also leads to activation of nucleic factor kappa $\mathrm{B}(\mathrm{NF \kappa B})$-mediated inflammation, aerosolized glutathione has been studied as a potential anti-inflammatory therapeutic in CF (Roum 1999).

Antiprotease, which plays an important role in the lung to counter the proteolytic products released by activated neutrophils, did not seem to be altered in the CF lung at baseline (Cartin AM 1991). However, these normal baseline levels were probably insufficient to neutralize the massive invasion of neutrophils and have thus been considered to be relatively deficient in the $\mathrm{CF}$ lung.

\subsubsection{Defective CFTR leads to release of inflammatory cytokines}

One of the dominant features of CF lung disease is the exaggerated inflammatory response. Numerous studies have linked the CFTR defect to activation of inflammatory cytokines, in particular interleukin-8 (IL-8). IL-8 is closely related to the CF inflammation as it is one of the major chemoattractants for neutrophils. Neutrophils dominate the inflammatory milieu in the CF lung. The importance of the vast number of neutrophils has been underscored by the successful use of recombinant DNAse to break down DNA released from neutrophils as one of the few effective therapeutics to ameliorate CF lung disease (Suri R 2002). Although it is still debated if inflammation precedes infection in the lungs of infants and young children with $\mathrm{CF}$, it is undisputed that CFTR is linked to the NFKB pathway, a crucial transcription activator for inflammatory and immune responses. These intrinsic activations of NFKB and cytokines, such as IL- 8 and tumor necrosis factor alpha (TNF- $\alpha$ ), have been observed both in naïve lung macrophages from CFTR knockout mice (CF mice) and in un-stimulated human macrophages with decreased CFTR expression (Bruscia EM 2008, Xu Y 2010). It seems that the intrinsic activation of NFKB-mediated inflammatory cytokine release is independent of the chloride channel function of the CFTR protein. Neutrophil elastase and other products of neutrophils, that are abundant in the CF lung, also induce IL-8 expression in epithelial cells (McElvaney NG 1992). Besides an increase in inflammatory cytokines, the CFTR defect has 
also been associated with a decrease in the anti-inflammatory cytokine interleukin-10 (IL10). Increased susceptibility to $C F$ pathogens such as Pseudomonas aeruginosa (P. aeruginosa) has been demonstrated in IL-10 deficient mice (Soltys J 2002).

\subsection{Abnormal cellular immune response in CF}

Cells of the innate and adaptive immune system have been studied in CF. The main findings are outlined in Table 2. As the role of epithelial cells in CF will be discussed in other chapters, the following details the functions and abnormalities seen in the neutrophils, macrophages, monocytes, dendritic cells, and lymphocytes that are likely playing a part in the pathogenesis of $\mathrm{CF}$ lung disease.

\subsubsection{Neutrophils}

Neutrophils are the dominating cell type in the inflammatory milieu of the CF airways. The content of their granules and products, in particular DNA and neutrophil elastase, contribute significantly to the $\mathrm{CF}$ lung damage. The increase in the serum and lung cytokine levels, especially of IL-8, preactivates neutrophils and lowers their threshold for granule release (Swain SD 2002). A number of abnormalities have been observed in CF neutrophils, including defective phagocytosis and oxidative burst (Alexis NE 2006), increased degranuation (myeloperoxidase) (Koller DY 1995), augmented proteolytic activity with elevated elastase and matrix metalloprotein release (Brockbank S 2005, Ratjen F 2002, Sagel SD 2005), increased apoptosis and chemotaxis (Brennan S 2001, Watt AP 2005), decreased acidification of phagolysosomes and reduced antimicrobial activity (Painter RG 2006), defective protein kinase C (Graff I 1991), and dysregulated cytokine secretion (Corvol H 2003). Blood neutrophils from CF patients were impaired in chlorination of ingested bacteria due to defective hypochlorous acid $(\mathrm{HOCl})$ production within phagolysosomes, whereas extracellular $\mathrm{HOCl}$ production was normal (Painter RG 2006). Profound functional and signaling changes have been shown in viable inflammatory neutrophils collected from airways of CF patients compared to their blood counterparts (Tirouvanziam R 2007). On CF airway neutrophils, the surface expression of phagocytosis receptors CD16 and CD14 was lost, whereas other lineage markers such as CD80 and MHCII appeared, indicating potential functional reprogramming (Tirouvanziam R 2007).

The study by Hartl D et al. has provided another pathophysiologic mechanism showing unopposed proteolytic cleavage of chemokine receptor CXCR1 on CF neutrophils and subsequent failure of their bacterial-killing capacity (Hartl D 2007). One of the most important features of the neutrophils in CF is their delayed apoptosis, which could be even measured in CF heterozygous individuals (Moriceau S 2010).

Toll-like receptors (TLRs) play crucial roles in the innate host defense against $P$. aeruginosa Neutrophils express all human TLRs except for TLR3. TLR2 and TLR5 present the main TLRs for the recognition of $P$. aeruginosa. TLR2 and TLR4 are involved in the cytokine response to $P$. aeruginosa infection. Intact flagellin/TLR5 signaling is a prerequisite for an efficient clearance of acute $P$. aeruginosa infection. The expression levels of TLRs in CF neutrophils have been investigated (Koll B 2008, Petit-Bertron AF 2008). Circulating and airway neutrophils from CF patients displayed a distinct pattern of surface markers as compared to the cells from healthy controls (Petit-Bertron AF 2008). CF blood neutrophils 


\begin{tabular}{|c|c|c|}
\hline Cell type & Function & Reference \\
\hline \multirow[t]{4}{*}{ Epithelial cells } & Bacterial killing & Moskwa P et al. 2007 \\
\hline & Transport of GSH ${ }^{1}$ & Velsor LW et al. 2001 \\
\hline & Redox balance & Xu Y et al. 2006 \\
\hline & Cytokine production & Tabary O et al. 2000 \\
\hline \multirow[t]{10}{*}{ Neutrophils } & Phagocytosis & $\begin{array}{l}\text { Morris MR et al. 2005, Alexis NE et al. } \\
2006\end{array}$ \\
\hline & & Gaggar A et al. 2007, Koller DY et al. 1995, \\
\hline & Degranulation & $\begin{array}{l}\text { Brockbank S et al. 2005, Ratjen F et al. } \\
\text { 2002, Sagel SD et al. } 2005\end{array}$ \\
\hline & Apoptosis & $\begin{array}{l}\text { Vandivier RW et al. 2002, Watt AP et al. } \\
2005\end{array}$ \\
\hline & Chemotaxis & Brennan S et al. 2001 \\
\hline & $\begin{array}{l}\text { Chlorination of } \\
\text { phagolysosomes }\end{array}$ & Painter RG et al. 2006 \\
\hline & Anti-microbial activity & $\begin{array}{l}\text { Painter RG et al. 2006, Moraes TJ et al. } \\
2006\end{array}$ \\
\hline & Cytokine production & $\begin{array}{l}\text { Corvol H et al. 2003, Tirouvanziam R et } \\
\text { al. } 2007\end{array}$ \\
\hline & CXCR1 ${ }^{2}$ cleavage & Hartl D et al. 2007 \\
\hline & TLR $^{3}-2,4,5$ expression & Petit Bertron AF et al. 2008 \\
\hline \multirow[t]{6}{*}{ Macrophages } & Clearance of apoptotic cells & Vandiview RW et al. 2002a, 2002b \\
\hline & Cytokine production & $\begin{array}{l}\text { Bonfield TL et al. 1995, Bruscia EM et al. } \\
2009 \text {, Brennan S et al. 2009, Xu Y et al. } \\
2010\end{array}$ \\
\hline & Phagocytosis & Knight RA et al. 1997, Di A et al. 2006 \\
\hline & Acidification of lysosomes & $\begin{array}{l}\text { Di A et al. 2006, Haggie PM, Verkman AS } \\
2007 \text { and } 2009\end{array}$ \\
\hline & Antigen presentation & Knight RA et al. 1997 \\
\hline & $\mathrm{PPAR}^{4} / \mathrm{LXR}^{5}$ regulation & Andersson C et al. 2007 \\
\hline \multirow[t]{3}{*}{ Dendritic cells } & $\begin{array}{l}\text { CD1d-restricted natural killer } \\
\mathrm{T} \text { cells activation }\end{array}$ & Rzemienaik SE et al. 2010 \\
\hline & Differentiation and maturation & Xu Y et al. 2009 \\
\hline & $\begin{array}{l}\text { Activation, antigen presentation, } \\
\text { and cytokine secretion }\end{array}$ & Roghanian A et al. 2006, Xu Y et al. 2009 \\
\hline \multirow[t]{6}{*}{ Monocytes } & Phagocytosis & del Fresno C et al. 2009 \\
\hline & Antigen presentation & Sorio C et al. 2011 \\
\hline & MHCII expression & del Fresno C et al. 2008 \\
\hline & TREM-16 expression & del Fresno C et al. 2008 \\
\hline & Cytokine production & del Fresno C et al. 2008 \\
\hline & Toll-2, 4 expression & Sturge N C et al. 2010 \\
\hline \multirow[t]{4}{*}{ Lymphocytes } & Chloride channel function & $\begin{array}{l}\text { McDonald TV et al.1992, Dong YJ et } \\
\text { al.1995, Moss RB et al.1996 }\end{array}$ \\
\hline & & $\begin{array}{l}\text { Knutsen AP et al.1989 and 1990, Lahat N } \\
\text { et al.1989, Moss RB et al.1996 and 2000, }\end{array}$ \\
\hline & Cytokine production & Hubeau C et al.2004, Hartl D et al.2005 \\
\hline & & Muller C et al.2010, Tan HL et al.2011 \\
\hline
\end{tabular}

Notes: ${ }^{1}$ GSH (glutathione); ${ }^{2}$ CXCR (C-X-C chemokine receptor), ${ }^{3}$ TLR (toll like receptor), ${ }^{4}$ PPAR (peroxisomal proliferator activated receptors), ${ }^{5}$ LXR (liver X receptors), ${ }^{6}$ TREM-1 (triggering receptor expressed on myeloid cells-1)

Table 2. Cellular immune dysfunction in $\mathrm{CF}$ 
expressed elevated levels of CD64, an activation marker, and lower levels of TLR2 compared to blood neutrophils from healthy controls (Petit-Bertron AF 2008). In contrast, CF airway neutrophils expressed an elevated level of TLR4 and spontaneously released IL-8 that was neither enhanced by microbial activators nor inhibited by recombinant human IL-10, indicating intrinsic resistance to anti-inflammatory signals delivered by IL-10 (Petit-Bertron AF 2008). A similar study by Koller B et al. investigated the expression levels of TLR2, TLR4, TLR5, and TLR9 on airway neutrophils compared to circulating neutrophils in CF patients infected with $P$. aeruginosa. TLR5 was the only TLR that was significantly higher expressed in CF airway neutrophils compared to the controls (Koller B 2008).

\subsubsection{Macrophages}

Alveolar macrophages (AM) are important as a first line host defense in the lung. Besides the phagocytosis of inhaled pathogens and apoptotic cells and the release of inflammatory mediators they play an important role in orchestrating innate immune defenses (Takabayshi 2006). One of the important regulatory functions of AM may be to dampen immune responses (Lambrecht 2006), so that dysfunction of AM in CF could be related to increased inflammation. The antigen-presenting capacity of AM is low, compared to other macrophages and a majority of their function is related to phagocytosis. Dysfunctional CFTR in macrophages has been linked to impaired clearance of apoptotic cells, pro-inflammatory cytokines production, deficient antigen presentation, abnormal TLR4 trafficking, decreased bactericidal activity, and defective phagocytosis (Bonfield TL 1995, Bruscia EM 2009 and 2011, del Porto P 2011, Di A 2006, Knight RA 1997, Vandivier RW 2002a and 2002b, Xu Y 2010). Lipopolysaccharide (LPS) stimulated peritoneal macrophages from CF mice showed increased TNF- $\alpha$ and IL-6 secretion as well as NFкB p65 activity. It also demonstrated attenuated induction of peroxisomal proliferator activated receptors (PPAR) and liver $X$ receptors (LXR), those are two mediators known as the inhibitory regulators of pro-inflammatory cytokines (Andersson C 2007). Bruscia et al. showed that macrophages directly contributed to the exaggerated inflammatory response following LPS administration in CF mice with increased secretion of cytokines including IL-6 and keratinocyte chemoattractant (Bruscia EM 2009). The same group also demonstrated that abnormal trafficking and degradation of TLR4 might underlie the elevated inflammatory response in CF (Bruscia EM 2011). Macrophages isolated from lavage samples from CF patients were not able to stimulate allogeneic lymphocytes and to present antigen, while peripheral blood monocytes from the same patients were functional in both assays (Knight RA 1997). Macrophages derived from peripheral blood from CF patients did not differ in phagocytic activity when infected with $P$. aeruginosa, whereas the percentage of surviving bacteria was significantly higher inside CF cells compared to the controls (del Porto P 2011). As $\mathrm{AM}$ in human $\mathrm{CF}$ lungs are highly activated by the inflammatory milieu, our group assessed the direct influence of CFTR on the function of AM by knockdown CFTR expression in normal human AM with siRNA silencing. A pro-inflammatory phenotype and increased apoptosis were seen in human AM with defective CFTR, possibly due to increased expression of the lipid raft protein Caveolin-1 (Xu Y 2010). The CFTR defect has been linked to augmented apoptosis with an abnormal cellular ceramide composition which is thought to be dependant on alteration in the lipid rafts in CF cells (Becker KA 2010). Altered pH of lysosome in CF macrophages has been suggested to induce defective acidification and bactericidal activity (Di A 2006). These findings have been disputed by others as the $\mathrm{pH}$ in the $\mathrm{CF}$ lysosomes was not altered using $\mathrm{pH}$ sensitive fluorescent probes (Haggie PM 2007 and 2009). 
Macrophages may be part of an abnormal priming process in CF during fetal development. This has been suggested by the analysis of fetal lungs for early features of immune dysregulation, which showed that the number of macrophages in the lung was higher in CF fetal lungs compared to non-CF lungs during the later stages of lung development (Hubeau 2001). Findings in the lungs of young infants with CF also point to the presence of increased macrophages as the macrophage recruiting CC chemokines elevated (Brennan S 2008; Starner 2003).

\subsubsection{Monocytes}

Peripheral blood monocytes, the precursors of AM, represent a pool of cells available to migrate to the lungs in response to bacterial infection. Abnormal functions of monocytes in peripheral blood from CF patients have been shown despite of absence of systemic infection in CF (del Fresno C 2008 and 2009, Sturges NC 2010, Zaman MM 2004). Augmented IL-8 secretions at baseline and in response to LPS were seen in monocytes of adult subjects heterozygous for $\triangle \mathrm{F} 508$ mutation, with no increased expression of LPS receptors including CD14 and TLR4 but possible association with alterations in mitogen activated phosphate kinase (MAPK) signaling (Zaman MM 2004). Blood peripheral monocytes isolated from CF patients were found to be locked in an endotoxin tolerance state in comparison to those exacted from healthy volunteers, not due to a deficient TLR activation but likely resulted from down-regulation of Triggering Receptor Expressed on Myeloid cells-1 (TREM-1) (del Fresno C 2008). Further investigation demonstrated potent phagocytic activity with impaired antigen presentation in LPS-tolerant monocytes from CF patients, possible by reason of decreased expression of $\mathrm{MHCII}$ and co-stimulatory molecules CD80, CD83, and CD86 (del Fresno C 2008). Contradictory to Zaman's finding, Sturge et al. have shown enhanced expression of TLR4 but similar TLR2 levels in monocytes from young CF patients with median age of 3.3 compared to healthy controls (Sturges NC 2010). The conflicting results may be due to difference in the age of subjects, and longitudinal studies are required to determine TLR4 expression as CF lung disease progresses.

\subsubsection{Dendritic cells}

Dendritic cells (DC), the most potent antigen presenting cells, are critical at the interface of innate and adaptive immune response. It is not known if DC function is affected in CF in humans. Only one study assessed blood-derived DC from CF patients in their capacity to activate CD1d-restricted natural killer T cells (NKT cells). The finding was that CF and non CF DC could comparably stimulate NKT cells with no apparent impact from defective CFTR chloride channel function (Rzemieniak SE 2010). Normal murine bone marrow derived DC (BMDC) were cultured in sputum from CF patients. These DC showed down-regulated expression of co-stimulatory molecules CD40, CD80, and CD86 (but not MHCII), inhibited LPS-induced activation, and defective antigen-presenting ability, partially owing to the inflammatory mediator neutrophil elastase (Roghanian A 2006). In our study, BMDC from CF mice expressed CFTR but were delayed in the early phase of differentiation. The expression levels of a number of genes related to lipid metabolism including caveolin-1, 3 $\beta$ hydroxysterol $-\Delta 7$ reductase (Dhcr7), and stearoyl-CoA desaturase 2 (Scd2) were altered (Xu $Y$ 2009). The roles of pulmonary DC, crucial in orchestrating innate and adaptive immune responses, have been investigated in lungs from CF mice in our laboratory ( $\mathrm{Xu}$ Y 2009). 
Phenotypic and functional abnormalities in CF lung DC were found including decreased numbers, altered maturation and activation profiles, and an impaired $\mathrm{T}$ cell-stimulation capacity. In response to respiratory syncytial virus infection, recruitment to the lung and $\mathrm{T}$ cell stimulatory potential of lung DC of CF mice were impaired in comparison to controls (Xu Y 2009). The dysfunctional CFTR might play a direct role in impaired lung DC. Indirect influence from the environment, where DC reside, on the phenotype and function of lung DC could not be excluded, although inflammation in lungs of CF mice at baseline is considerably mild compared to lungs of CF patients. Further investigation is undertaken to elucidate the mechanism of mal-functional DC in CF lungs.

\subsubsection{Lymphocytes}

Like the other immune cells, lymphocytes express CFTR and CF lymphocytes have a defective cAMP-regulated chloride channel function (Dong YJ 1995, McDonald TV 1992). B-lymphocytes from $\mathrm{CF}$ patients produced similar amounts of IgG compared to non-CF cells, but showed resistance to dexamethasone. This was proposed as a potential factor for the susceptibility to bacterial bronchopulmonary infections (Emilie D 1990). Selective cytokine dysregulation has been shown in $\mathrm{CF} C D 4^{+} \mathrm{T}$ cells after maximal activation with anti-CD3 or phorbol myristate acetate. It included decreased IFN- $\gamma$ secretion and reduced IL-10 production, whereas the levels of IL-2, IL-4, and IL-5 remained similar to controls (Moss RB 1996 and 2000). IL-2 has been known to stimulate the growth, differentiation and survival of antigen-selected cytotoxic $\mathrm{T}$ cells. IL-4 is a cytokine that induces differentiation of naïve helper T cells (Th0 cells) to Th2 cells. The functions of IL-5 are to stimulate B cell growth and increase immunoglobulin secretion.

Lymphocytes from CF patients or CF mice showed a profile skewed towards $\mathrm{T}_{\mathrm{H}} 2$ (Hartl D 2005, Mueller C 2010). In CF patients with P. aeruginosa infection, the prevalence of a pulmonary $\mathrm{T}_{\mathrm{H}} 2$ immune response has been shown with higher levels of CCR4 $4^{+} \mathrm{CD} 4^{+}\left(\mathrm{T}_{\mathrm{H}} 2\right)$ cells, increased levels of IL-4, IL-13, and lower levels of IFN- $\gamma$ compared with non-infected patients with CF and healthy controls (Hartl D 2005). Comparably, CF mice mounted an exaggerated IgE response upon Aspergillus fumigatus infection in the lung with increased levels of IL-4 and IL-13, mimicking both the $\mathrm{T}_{\mathrm{H}} 2$ biased immune responses seen in CF patients (Mueller C 2010). Similar findings are also reported in studies with peripheral blood derived monocytes or whole blood cultures from $C F$ patients infected with $P$. aeruginosa (Brazova J 2005, Moser C 2000). A dysregulated $T_{H} 1 / 2$ response might contribute to the impaired clearance of pathogens in CF.

Recently, more attention has been focused on the role of $\mathrm{T}_{\mathrm{H}} 17$ cells and interleukin-17 (IL-17) in the CF lung disease (McAllister F 2005, Tan HL 2011). IL-17 receptor signaling is critical for pulmonary neutrophil recruitment and host defense against Gram-negative bacteria through the coordinated release of granulocyte-colony stimulating factor (G-CSF) and CXC chemokine elaboration (Steinman L 2007, Bettelli 2007). Significantly elevated levels of IL17A, IL-17F and IL-17R were found in the sputum of patients with CF who were colonized with $P$. aeruginosa at the time of pulmonary exacerbation. These levels were declined with therapy directed against $P$. aeruginosa (McAllister $F$ 2005). $\mathrm{T}_{\mathrm{H}} 17$ lymphocytes and other $\mathrm{T}_{\mathrm{H}} 17^{+}$cells, including neutrophils, $\gamma \delta \mathrm{T}$ cells, and natural killer $\mathrm{T}$ cells, have been shown to be present in the airway sub-mucosa in $\mathrm{CF}$ patients even in a young, newly diagnosed group. Highest levels of IL-17 were found in bronchoalveolar lavage from established CF 
compared to the controls, with a significant correlation between IL-17 and neutrophil counts as well as IL-4 (Tan HL 2011). IL-17 pathway could serve as a new therapeutic candidate for $\mathrm{CF}$, while the exact pathogenic mechanisms of IL-17 in CF still remain to be elucidated.

\section{Conclusion}

Augmented inflammation, increased susceptibility of the respiratory tract for infections and lack of efficient clearance of the pathogens are features of a defective immune function. Abnormal CFTR chloride channel function (and potentially associated sodium hyperabsorption) in epithelial and mucous gland cells in the lung can only partially explain the pathophysiology of CF lung disease. Members of the innate and adaptive immune system are clearly affected by the milieu created by the altered salt and water composition. There is also evidence that CFTR dysfunction directly affects immune responses, probably beyond the stimulation of inflammatory cytokines. CFTR is expressed and is functional in a variety of immune cells. CFTR-related abnormalities have been shown in neutrophils, macrophages, monocytes, dendritic cells, and lymphocytes independent of exposure to the CF milieu of the respiratory tract as demonstrated in Fig 1. Thus, direct CFTR-mediated dysfunction of these cells may play a role in the enigmatic CF lung disease.

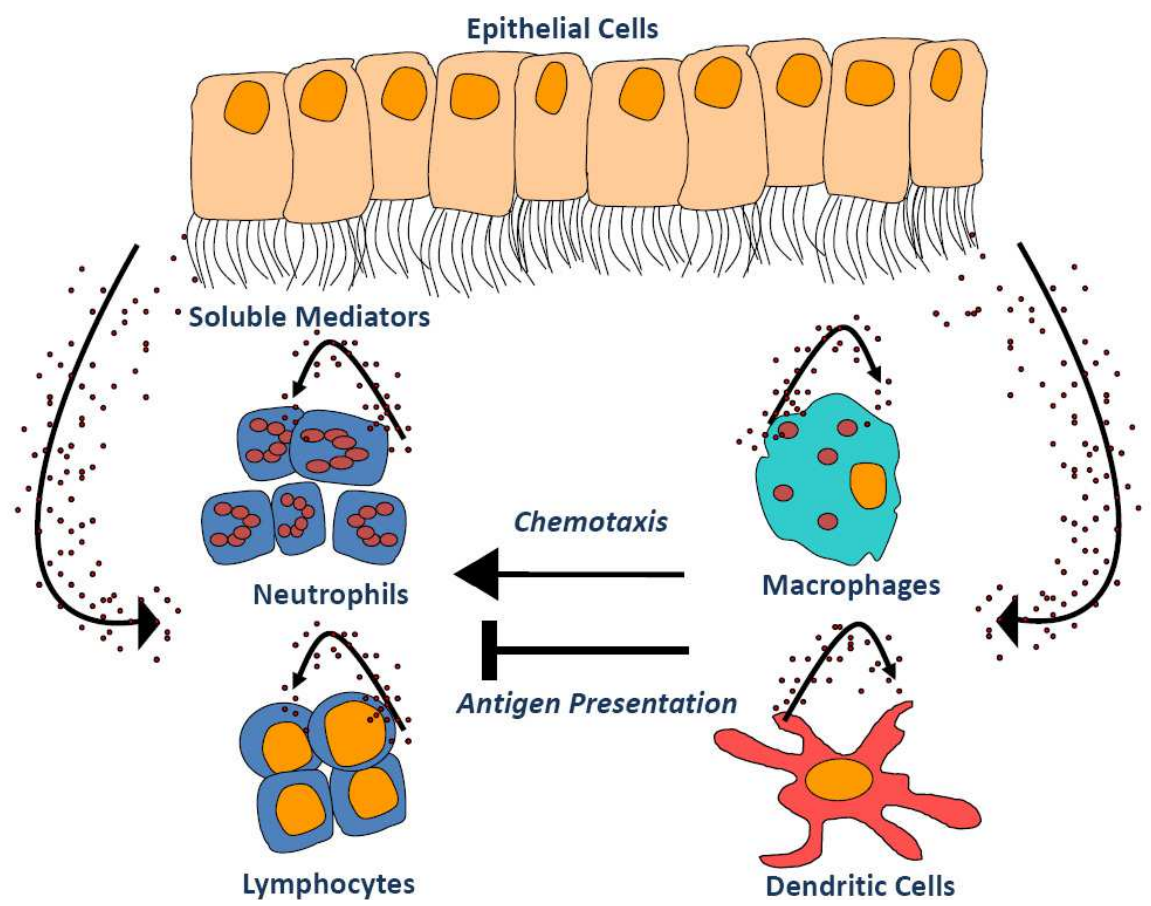

Fig. 1. Model of abnormal humoral and cellular immune responses in the CF lung. Altered humoral responses are comprised of soluble mediators including cytokines, chemokines, antioxidants, and antiproteases. Neutrophils, macrophages, dendritic cells, and lymphocytes are either affected by the altered soluble mediators from the CFTR-deficient epithelial and immune cells or by their own defective CFTR function. 


\section{Acknowledgment}

We thank Ms. Christine Filner for excellent assistance in the preparation of this manuscript. Our studies were supported by R21 HL077557 and the Cystic Fibrosis Foundation XU09F0, Bethesda, MD.

\section{References}

Alexis, N.E., M.S.Muhlebach, D.B.Peden, and T.L.Noah. (2006). Attenuation of Host Defense Function of Lung Phagocytes in Young Cystic Fibrosis Patients. Journal of Cystic Fibrosis 5:17-25. ISSN 1569-1993

Andersson, C., M.M.Zaman, A.B.Jones, and S.D.Freedman. (2008). Alterations in Immune Response and PPAR/LXR Regulation in Cystic Fibrosis Macrophages. Journal of Cystic Fibrosis 7:68-78. ISSN 1569-1993

Armstrong, D.S., S.M.Hook, K.M.Jamsen, G.M.Nixon, R.Carzino, J.B.Carlin, C.F.Robertson, and K.Grimwood. (2005). Lower Airway Inflammation in Infants with Cystic Fibrosis Detected by Newborn Screening. Pediatr. Pulmonol. 40:500-510. ISSN 87556863

Armstrong, D., K.Grimwood, J.Carlin, R.Carzino, J.Gutièrrez, J.Hull, A.Olinsky, E.Phelan, C.Robertson, and P.Phelan. (1997). Lower Airway Inflammation in Infants and Young Children with Cystic Fibrosis. Am. J. Respir. Crit. Care Med. 156:1197-1204. ISSN 1073-449X

Assef, Y.A., A.E.Damiano, E.Zotta, C.Ibarra, and B.A.Kotsias. (2003). CFTR in K562 Human Leukemic Cells. Am J Physiol Cell Physiol 285:C480-C488. ISSN 0363-6143

Bals, R., D.J.Weiner, R.L.Meegalla, F.Accurso, and J.M.Wilson. (2001). Salt-independent Abnormality of Antimicrobial Activity in Cystic Fibrosis Airway Surface Fluid. Am. J. Respir. Cell Mol. Biol. 25:21-25. ISSN:1044-1549

Bals, R., D.J.Weiner, and J.M.Wilson. (1999). The Innate Immune System in Cystic Fibrosis Lung Disease. J Clin Invest 103:303-307. ISSN 0021-9738

Bartlett J, Fischer A, and J.McCray PB. (2008). Innate Immune Functions of the Airway Epithelium. In Trends in Innate Immunity.Contrib Microbiol. Egesten A, Schmidt A, and Herwald H, editors. S Karger, ISBN 3805585489, Basel. 147-163.

Bhattacharyya, S., U.Gutti, J.Mercado, C.Moore, H.B.Pollard, and R.Biswas. (2010). MAPK Signaling Pathways Regulate IL-8 mRNA Stability and IL-8 Protein Expression in Cystic Fibrosis Lung Epithelial Cells Lines. Am J Physiol Lung Cell Mol Physiol doi:10.1152/ajplung.00051.2010. ISSN 1040-0605

Black, H.R., J.R.Yankaskas, L.G.Johnson, and T.L.Noah. (1998). Interleukin-8 Production by Cystic Fibrosis Nasal Epithelial Cells after Tumor Necrosis Factor-alpha and Respiratory Syncytial Virus Stimulation. Am. J. Respir. Cell Mol. Biol. 19:210-215. ISSN:1044-1549

Bonfield, T.L., J.R.Panuska, M.W.Konstan, K.A.Hilliard, J.B.Hilliard, H.Ghnaim, and M.Berger. (1995). Inflammatory Cytokines in Cystic Fibrosis Lungs. Am. J. Respir. Crit. Care Med. 152:2111-2118. ISSN: 1073-449X

Brazova, J., A.Sediva, D.Pospisilova, V.Vavrova, P.Pohunek, J.Macek, J.Bartunkova, and H.Lauschmann. (2005). Differential Cytokine Profile in Children with Cystic Fibrosis. Clin Immunol 115:210-215. ISSN:1521-6616 
Brennan, S., D.Cooper, and P.D.Sly. (2001). Directed Neutrophil Migration to IL-8 is Increased in Cystic Fibrosis: a Study of the Effect of Erythromycin. Thorax 56:62-64. ISSN 0040-6376

Brennan, S., P.D.Sly, C.L.Gangell, N.Sturges, K.Winfield, M.Wikstrom, S.Gard, J.W.Upham, and on behalf of AREST CF. (2009). Alveolar Macrophages and CC Chemokines are Increased in Children with Cystic Fibrosis. European Respiratory Journal 34:655-661. ISSN 0903-1936

Brennan, S. (2008). Innate Immune Activation and Cystic Fibrosis. Paediatric Respiratory Reviews 9:271-280. ISSN 1526-0542

Brockbank, S., D.Downey, J.S.Elborn, and M.Ennis. (2005). Effect of Cystic Fibrosis Exacerbations on Neutrophil Function. International Immunopharmacology 5:601-608. ISSN 1567-5769

Bruscia, E.M., P.X.Zhang, A.Satoh, C.Caputo, R.Medzhitov, A.Shenoy, M.E.Egan, and D.S.Krause. (2011). Abnormal Trafficking and Degradation of TLR4 Underlie the Elevated Inflammatory Response in Cystic Fibrosis. J Immunol 186:6990-6998. ISSN 0022-1767

Bruscia, E.M., P.X.Zhang, E.Ferreira, C.Caputo, J.W.Emerson, D.Tuck, D.S.Krause, and M.E.Egan. (2008). Macrophages Directly Contribute to the Exaggerated Inflammatory Response in CFTR-/- Mice. Am. J. Respir. Cell Mol. Biol. 40:295-304. ISSN 1044-1549

Bubien, J. (2001). CFTR may Play a Role in Regulated Secretion by Lymphocytes: a New Hypothesis for the Pathophysiology of Cystic Fibrosis. Pflugers Arch 443:S36-S39. ISSN 0031-6768

Buchanan, P.J., R.K.Ernst, J.S.Elborn, and B.Schock. (2009). Role of CFTR, Pseudomonas aeruginosa and Toll-like Receptors in Cystic Fibrosis Lung Inflammation. Biochem Soc Trans 37:863-867. ISSN 0300-5127

Cantin, A.M., S.Lafrenaye, and R.O.Begin. (1991). Antineutrophil Elastase Activity in Cystic Fibrosis Serum. Pediatr. Pulmonol. 11:249-253. ISSN 8755-6863

Chen CI, Schaller-Bals S, Paul KP, Wahn U, and Bals R. (2004). Beta-defensins and LL-37 in Bronchoalveolar Lavage Fluid of Patients with Cystic Fibrosis. Journal of Cystic Fibrosis 3:45-50. ISSN 1569-1993

Childers, M., G.Eckel, A.Himmel, and J.Caldwell. (2007). A New Model of Cystic Fibrosis Pathology: Lack of Transport of Glutathione and its Thiocyanate Conjugates. Medical Hypotheses 68:101-112. ISSN 0306-9877

Conese, M. (2011). Cystic Fibrosis and the Innate Immune System: Therapeutic Implications. Endocr. Metab Immune. Disord. Drug Targets. 11:8-22. ISSN 1871-5303

Corvol, H., C.Fitting, K.Chadelat, J.Jacquot, O.Tabary, M.Boule, J.M.Cavaillon, and A.Clement. (2003). Distinct Cytokine Production by Lung and Blood Neutrophils from Children with Cystic Fibrosis. American Journal of Physiology - Lung Cellular and Molecular Physiology 284:L997-L1003. ISSN 1522-1504

Day, B.J. (2005). Glutathione: a Radical Treatment for Cystic Fibrosis Lung Disease? Chest 127:12-14. ISSN 0012-3692

Deriy, L.V., E.A.Gomez, G.Zhang, D.W.Beacham, J.A.Hopson, A.J.Gallan, P.D.Shevchenko, V.P.Bindokas, and D.J.Nelson. (2009). Disease Causing Mutations in the Cystic Fibrosis Transmembrane Conductance Regulator Determine the Functional Responses of Alveolar Macrophages. Journal of Biological Chemistry. ISSN 0021-9258 
del Fresno, C., F.Garcia-Rio, V.Gomez-Pina, A.Soares-Schanoski, I.Fernandez-Ruiz, T.Jurado, T.Kajiji, C.Shu, E.Marin, A.Gutierrez del Arroyo, C.Prados, F.Arnalich, P.Fuentes-Prior, S.K.Biswas, and E.Lopez-Collazo. (2009). Potent Phagocytic Activity with Impaired Antigen Presentation Identifying Lipopolysaccharidetolerant Human Monocytes: Demonstration in Isolated Monocytes from Cystic Fibrosis Patients. J Immunol 182:6494-6507. ISSN 0022-1767

del Fresno, C., V.Gomez-Pina, V.Lores, A.Soares-Schanoski, I.Fernandez-Ruiz, B.Rojo, R.varez-Sala, E.Caballero-Garrido, F.Garcia, T.Veliz, F.Arnalich, P.Fuentes-Prior, F.Garcia-Rio, and E.Lopez-Collazo. 2008. Monocytes from Cystic Fibrosis Patients are Locked in an LPS Tolerance State: Down-Regulation of TREM-1 as Putative Underlying Mechanism. PLoS ONE 3:e2667. ISSN 1932-6203

Di, A., M.E.Brown, L.V.Deriy, C.Li, F.L.Szeto, Y.Chen, P.Huang, J.Tong, A.P.Naren, V.Bindokas, H.C.Palfrey, and D.J.Nelson. (2006). CFTR Regulates Phagosome Acidification in Macrophages and Alters Bactericidal Activity. Nat Cell Biol 8:933944. ISSN 1465-7392

dib-Conquy, M., T.Pedron, A.F.Petit-Bertron, O.Tabary, H.Corvol, J.Jacquot, A.Clement, and J.M.Cavaillon. (2008). Neutrophils in Cystic Fibrosis Display a Distinct Gene Expression Pattern. Mol Med 14:36-44. ISSN 1432-1440

Dong, Y.J., A.C.Chao, K.Kouyama, Y.P.Hsu, R.C.Bocian, R.B.Moss, and P.Gardner. (1995.) Activation of CFTR Chloride Current by Nitric Oxide in Human T Lymphocytes. EMBO J 14:2700-2707. ISSN 0261-4189

Gaggar, A., A.Hector, P.E.Bratcher, M.A.Mall, M.Griese, and D.Hartl. (2011). The Role of Matrix Metalloproteinases in Cystic Fibrosis Lung Disease. European Respiratory Journal 38:721-727. 0903-1936

Gaggar, A., Y.Li, N.Weathington, M.Winkler, M.Kong, P.Jackson, J.E.Blalock, and J.P.Clancy. (2007). Matrix Metalloprotease-9 Dysregulation in Lower Airway Secretions of Cystic Fibrosis Patients. American Journal of Physiology Lung Cellular and Molecular Physiology 293:L96-L104. ISSN 1040-0605

Gao, L., K.J.Kim, J.R.Yankaskas, and H.J.Forman. (1999). Abnormal Glutathione Transport in Cystic Fibrosis Airway Epithelia. American Journal of Physiology - Lung Cellular and Molecular Physiology 277:L113-L118. ISSN 1040-0605

Goldman, M.J., G.M.Anderson, E.D.Stolzenberg, U.P.Kari, M.Zasloff, and J.M.Wilson. (1997). Human [beta]-Defensin-1 Is a Salt-Sensitive Antibiotic in Lung That Is Inactivated in Cystic Fibrosis. Cell 88:553-560. ISSN 0092-8674

Haggie, P.M. and A.S.Verkman. (2009). Unimpaired Lysosomal Acidification in Respiratory Epithelial Cells in Cystic Fibrosis. J Biol Chem 284:7681-7686. ISSN 0021-9258

Hampton, T.H. and B.A.Stanton. (2010). A Novel Approach to Analyze Gene Expression Data Demonstrates that the \{Delta\}F508 Mutation in CFTR Downregulates the Antigen Presentation Pathway. Am J Physiol Lung Cell Mol Physiol 298:L473-L482. ISSN 1040-0605

Hartl, D. and M.Griese. (2006). Surfactant Protein D in Human Lung Diseases. European Journal of Clinical Investigation 36:423-435. ISSN 1526-0542

Hartl, D., M.Griese, M.Kappler, G.Zissel, D.Reinhardt, C.Rebhan, D.J.Schendel, and S.Krauss-Etschmann. (2006). Pulmonary TH2 Response in Pseudomonas aeruginosa-infected Patients with Cystic Fibrosis. J Allergy Clin Immunol 117:204211. ISSN 0091-6749 
Hauber, H.P., M.K.Tulic, A.Tsicopoulos, B.Wallaert, R.Olivenstein, P.Daigneault, and Q.Hamid. (2005). Toll-like Receptors 4 and 2 Expression in the Bronchial Mucosa of Patients with Cystic Fibrosis. Can. Respir J 12:13-18. ISSN 1198-2241

Hausler, M., K.Schweizer, S.Biesterfeld, T.Opladen, and G.Heimann. (2002). Peripheral Decrease and Pulmonary Homing of CD4+CD45RO+ Helper Memory T cells in Cystic Fibrosis. Respiratory Medicine 96:87-94. ISSN 0954-6111

Hubeau, C., E.Puchelle, and D.Gaillard. (2001). Distinct Pattern of Immune Cell Population in the Lung of Human Fetuses with Cystic Fibrosis. Journal of Allergy and Clinical Immunology 108:524-529. ISSN 0091-6749

Hudson, V.M. (2001). Rethinking Cystic Fibrosis Pathology: the Critical Role of Abnormal Reduced Glutathione (GSH) Transport Caused by CFTR Mutation. Free Radical Biology and Medicine 30:1440-1461. ISSN 0891-5849

Jacquot, J., O.Tabary, P.Le Rouzic, and A.Clement. (2008). Airway Epithelial Cell Inflammatory Signalling in Cystic Fibrosis. The International Journal of Biochemistry $\mathcal{E}$ Cell Biology 40:1703-1715. ISSN 1357-2725

Kerby, G.S., V.Cottin, F.J.Accurso, F.Hoffmann, E.D.Chan, V.A.Fadok, and D.W.H.Riches. (2002). Impairment of Macrophage Survival by $\mathrm{NaCl}$ : Implications for Early Pulmonary Inflammation in Cystic Fibrosis. American Journal of Physiology - Lung Cellular and Molecular Physiology 283:L188-L197. ISSN 1040-0605

Khan, T.Z., J.S.Wagener, T.Bost, J.Martinez, F.J.Accurso, and D.W.Riches. (1995). Early Pulmonary Inflammation in Infants with Cystic Fibrosis. Am. J. Respir. Crit. Care Med. 151:1075-1082. ISSN 1073-449X

Knight, R.A., S.Kollnberger, B.Madden, M.Yacoub, and M.E.Hodson. (1997). Defective Antigen Presentation by Lavage Cells from Terminal Patients with Cystic Fibrosis. Clin Exp Immunol 107:542-547. ISSN 0009-9104

Knutsen, A.P. and R.G.Slavin. (1989). In vitro T cell Responses in Patients with Cystic Fibrosis and Allergic Bronchopulmonary Aspergillosis. J Lab Clin Med. 113:428-435. ISSN 0022-2143

Knutsen, A.P., K.R.Mueller, P.S.Hutcheson, and R.G.Slavin. (1990). T- and B-cell Dysregulation of IgE Synthesis in Cystic Fibrosis Patients with Allergic Bronchopulmonary Aspergillosis. Clinical Immunology and Immunopathology 55:129138. ISSN 0090-1229

Kogan, I., M.Ramjeesingh, C.Li, J.F.Kidd, Y.Wang, E.M.Leslie, S.P.C.Cole, and C.E.Bear. (2003). CFTR Directly Mediates Nucleotide-regulated Glutathione Flux. EMBO J 22:1981-1989. I SSN 0261-4189

Koller, B., M.Kappler, P.Latzin, A.Gaggar, M.Schreiner, S.Takyar, M.Kormann, M.Kabesch, D.Roos, M.Griese, and D.Hartl. (2008). TLR Expression on Neutrophils at the Pulmonary Site of Infection: TLR1/TLR2-Mediated Up-Regulation of TLR5 Expression in Cystic Fibrosis Lung Disease. J Immunol 181:2753-2763. ISSN 00221767

Koller, D.Y., R.Urbanek, and M.Gotz. (1995). Increased Degranulation of Eosinophil and Neutrophil Granulocytes in Cystic Fibrosis. Am J Respir Crit Care Med 152:629-633. ISSN 1073-449X

Lahat, N., J.Rivlin, and T.C.Iancu. (1989). Functional Immunoregulatory T-cell Abnormalities in Cystic Fibrosis Patients. J Clin Immunol 9:287-295. ISSN 0271-9142 
Mall, M.A., B.Button, B.Johannesson, Z.Zhou, A.Livraghi, R.A.Caldwell, S.C.Schubert, C.Schultz, W.K.O'Neal, S.Pradervand, E.Hummler, B.C.Rossier, B.R.Grubb, and R.C.Boucher. (2010). Airway Surface Liquid Volume Regulation Determines Different Airway Phenotypes in Liddle Compared with betaENaC-overexpressing Mice. Journal of Biological Chemistry 285:26945-26955. ISSN 0021-9258

McAllister, F., A.Henry, J.L.Kreindler, P.J.Dubin, L.Ulrich, C.Steele, J.D.Finder, J.M.Pilewski, B.M.Carreno, S.J.Goldman, J.Pirhonen, and J.K.Kolls. (2005). Role of IL-17A, IL-17F, and the IL-17 Receptor in Regulating Growth-Related Oncogene-+ $\mid$ and Granulocyte Colony-Stimulating Factor in Bronchial Epithelium: Implications for Airway Inflammation in Cystic Fibrosis. J Immunol 175:404-412. ISSN 022-1767

McDonald, T.V., P.T.Nghiem, P.Gardner, and C.L.Martens. (1992). Human Lymphocytes Transcribe the Cystic Fibrosis Transmembrane Conductance Regulator Gene and Exhibit CF-defective cAMP-regulated Chloride Current. Journal of Biological Chemistry 267:3242-3248. ISSN 0021-9258

McElvaney, N.G., H.Nakamura, P.Birrer, C.A.H+ᄀbert, W.L.Wong, M.Alphonso, J.B.Baker, M.A.Catalano, and R.G.Crystal. (1992). Modulation of Airway Inflammation in Cystic Fibrosis. In vivo Suppression of Interleukin-8 Levels on the Respiratory Epithelial Surface by Aerosolization of Recombinant Secretory Leukoprotease Inhibitor. J Clin Invest 90:1296-1301.ISSN 0021-9738

Meyer, K.C., A.Sharma, R.Brown, M.Weatherly, F.R.Moya, J.Lewandoski, and J.J.Zimmerman. (2000). Function and Composition of Pulmonary Surfactant and Surfactant-derived Fatty Profiles are Altered in Young Adults with Cystic Fibrosis. Chest 118:164-174. ISSN 0012-3692

Meyer, M., F.Huaux, X.Gavilanes, S.van den Brule, P.Lebecque, S.Lo Re, D.Lison, B.Scholte, P.Wallemacq, and T.Leal. (2009). Azithromycin Reduces Exaggerated Cytokine Production by M1 Alveolar Macrophages in Cystic Fibrosis. Am. J. Respir. Cell Mol. Biol. 41:590-602. ISSN 1044-1549

Moraes, T.J., J.Plumb, R.Martin, E.Vachon, V.Cherepanov, A.Koh, C.Loeve, J.Jongstra-Bilen, J.H.Zurawska, J.V.Kus, L.L.Burrows, S.Grinstein, and G.P.Downey. (2006). Abnormalities in the Pulmonary Innate Immune System in Cystic Fibrosis. Am. J. Respir. Cell Mol. Biol. 34:364-374. ISSN 1044-1549

Morris, M.R., I.J.M.Doull, S.Dewitt, and M.B.Hallett. (2005). Reduced iC3b-mediated Phagocytotic Capacity of Pulmonary Neutrophils in Cystic Fibrosis. Clinical $\mathcal{E}$ Experimental Immunology 142:68-75. ISSN 1365-2249

Moskwa, P., D.Lorentzen, K.J.D.A.Excoffon, J.Zabner, P.B.McCray, Jr., W.M.Nauseef, C.Dupuy, and B.Banfi. (2007). A Novel Host Defense System of Airways is Defective in Cystic Fibrosis. Am. J. Respir. Crit. Care Med. 175:174-183. ISSN 1073449X

Moss, R.B., R.C.Bocian, Y.P.Hsu, Y.J.Dong, M.KEMNA, T.WEI, and P.Gardner. (1996). Reduced IL-10 Secretion by CD4+ T Lymphocytes Expressing Mutant Cystic Fibrosis Transmembrane Conductance Regulator (CFTR). Clinical E Experimental Immunology 106:374-388. ISSN 1365-2249

Moss, R.B., Y.P.Hsu, and L.Olds. (2000). Cytokine Dysregulation in Activated Cystic Fibrosis (CF) Peripheral Lymphocytes. Clinical E Experimental Immunology 120:518-525. ISSN 1365-2249 
Mueller, C., S.A.Braag, A.Keeler, C.Hodges, M.Drumm, and T.R.Flotte. (2010). Lack of Cftr in CD3+ Lymphocytes Leads to Aberrant Cytokine Secretion and Hyperinflammatory Adaptive Immune Responses. Am. J. Respir. Cell Mol. Biol.doi:10.1165/rcmb.2010-0224OC. ISSN 1044-1549

Noah, T.L., P.C.Murphy, J.J.Alink, M.W.Leigh, W.M.Hull, M.T.Stahlman, and J.A.Whitsett. (2003). Bronchoalveolar Lavage Fluid Surfactant Protein-A and Surfactant ProteinD Are Inversely Related to Inflammation in Early Cystic Fibrosis. Am. J. Respir. Crit. Care Med. 168:685-691. ISSN 1073-449X

Nurlan Dauletbaev, Roswitha Gropp, Michaela Frye, Stefan Loitsch, Thomas-Otto-Friedrich Wagner, and Joachim Bargon. (2002). Expression of Human Beta Defensin (HBD-1 and HBD-2) mRNA in Nasal Epithelia of Adult Cystic Fibrosis Patients, Healthy Individuals, and Individuals with Acute Cold. Respiration 69:46-51. ISSN 1423-0356

Painter, R.G., R.W.Bonvillain, V.G.Valentine, G.A.Lombard, S.G.LaPlace, W.M.Nauseef, and G.Wang. (2008). The Role of Chloride Anion and CFTR in Killing of Pseudomonas aeruginosa by Normal and CF Neutrophils. J Leukoc Biol 83:1345-1353. ISSN 07415400

Petit-Bertron, A.F., O.Tabary, H.Corvol, J.Jacquot, A.Clqment, J.M.Cavaillon, and M.dibConquy. (2008). Circulating and Airway Neutrophils in Cystic Fibrosis Display Different TLR Expression and Responsiveness to Interleukin-10. Cytokine 41:54-60. ISSN 1043-4666

Ratjen, F. and G.Doring. (2003). Cystic Fibrosis. The Lancet 361:681-689. ISSN 0140-6736

Roghanian, A., E.M.Drost, W.MacNee, S.E.M.Howie, and J.M.Sallenave. (2006). Inflammatory Lung Secretions Inhibit Dendritic Cell Maturation and Function via Neutrophil Elastase. Am. J. Respir. Crit. Care Med. 174:1189-1198. ISSN 1073-449X

Roum, J.H., R.Buhl, N.G.McElvaney, Z.Borok, and R.G.Crystal. (1993). Systemic Deficiency of Glutathione in Cystic Fibrosis. Journal of Applied Physiology 75:2419-2424. ISSN 8750-7587

Rzemieniak, S.E., A.F.Hirschfeld, R.E.Victor, M.A.Chilvers, D.Zheng, P.Van Den Elzen, and S.E.Turvey. (2010). Acidification-dependent Activation of CD1d-restricted Natural Killer T cells is Intact in Cystic Fibrosis. Immunology 130:288-295. ISSN 1365-2567

Sagel, S.D., R.K.Kapsner, and I.Osberg. (2005). Induced Sputum Matrix Metalloproteinase-9 Correlates with Lung Function and Airway Inflammation in Children with Cystic Fibrosis. Pediatr. Pulmonol. 39:224-232. ISSN 1099-0496

Soltys, J., T.Bonfield, J.Chmiel, and M.Berger. (2002). Functional IL-10 Deficiency in the Lung of cystic fibrosis (cftr-/-) and IL-10 Knockout Mice causes Increased Expression and Function of B7 Costimulatory Molecules on Alveolar Macrophages. J Immunol 168:1903-1910. ISSN 0022-1767

Sturges, N.C., M.E.Wikstrim, K.R.Winfield, S.E.Gard, S.Brennan, P.D.Sly, and J.W.Upham. (2010). Monocytes from Children with Clinically Stable Cystic Fibrosis Show Enhanced Expression of Toll-like Receptor 4. Pediatr. Pulmonol. 45:883-889. ISSN 8755-6863

Suri, R., L.J.Marshall, C.Wallis, C.Metcalfe, A.Bush, and J.K.Shute. (2002). Effects of Recombinant Human DNase and Hypertonic Saline on Airway Inflammation in Children with Cystic Fibrosis. Am. J. Respir. Crit. Care Med. 166:352-355. ISSN 1073449X 
Tabary, O., S.Escotte, J.Couetil, D.Hubert, D.Dusser, E.Puchelle, and J.Jacquot. (2001). Relationship Between IkappaBa Deficiency, NFkappaB Activity and Interleukin-8 Production in CF Human Airway Epithelial Cells. Pflugers Archiv European Journal of Physiology 443:S40-S44. ISSN 0031-6768

Tan, H.L., N.Regamey, S.Brown, A.Bush, C.M.Lloyd, and J.C.Davies. (2011). The Th17 Pathway in Cystic Fibrosis Lung Disease. Am. J. Respir. Crit. Care Med. 184:252-258. ISSN 1073-449X

Tirouvanziam, R. (2006). Neutrophilic Inflammation as a Major Determinant in the Progression of Cystic Fibrosis. Drug News Perspect. 19:609-614. ISSN 0214-0934

Vandivier, R.W., V.A.Fadok, P.R.Hoffmann, D.L.Bratton, C.Penvari, K.K.Brown, J.D.Brain, F.J.Accurso, and P.M.Henson. (2002a). Elastase-mediated Phosphatidylserine Receptor Cleavage Impairs Apoptotic Cell Clearance in Cystic Fibrosis and Bronchiectasis. Journal of Clinical Investigation 109:661. ISSN 0021-9738

Vandivier, R.W., V.A.Fadok, C.A.Ogden, P.R.Hoffmann, J.D.Brain, F.J.Accurso, J.H.Fisher, K.E.Greene, and P.M.Henson. (2002b). Impaired Clearance of Apoptotic Cells From Cystic Fibrosis Airways. Chest 121:89S. ISSN 0012-3692

Velsor, L.W., A.van Heeckeren, and B.J.Day. (2001). Antioxidant Imbalance in the Lungs of Cystic Fibrosis Transmembrane Conductance Regulator Protein Mutant Mice. American Journal of Physiology - Lung Cellular and Molecular Physiology 281:L31-L38. ISSN 1522-1504

Watt, A.P., J.Courtney, J.Moore, M.Ennis, and J.S.Elborn. (2005). Neutrophil Cell Death, Activation and Bacterial Infection in Cystic Fibrosis. Thorax 60:659-664. ISSN 00406376

Welsh MJ, Ramsey BW, Accurso F, and Cutting GR. (2011). Cystic Fibrosis. In the Online Metabolic \& Molecular Bases of Inherited Disease. Charles R.Scriver, editor. McGraw-Hill, ISBN 0079130356, New York.

Xu, Y., C.Liu, J.C.Clark, and J.A.Whitsett. (2006). Functional Genomic Responses to Cystic Fibrosis Transmembrane Conductance Regulator (CFTR) and CFTRdeltaF508 in the Lung. Journal of Biological Chemistry 281:11279-11291. ISSN 0021-9258

$\mathrm{Xu}$ Y, Krause A, Wu W, Joh J, Limberis MP, and Worgall S. Characterization of Pulmonary Dendritic Cell in the Lung Disease of Cystic Fibrosis Mice following Respiratory Syncytial Virus Infection. American Thoracic Society 2009 International Conference. The American Journal of Respiratory and Critical Care Medicine ISSN 1535-4970, San Diego, California, USA, May 15-20, 2009.

Xu, Y., A.Krause, H.Hamai, B.G.Harvey, T.S.Worgall, and S.Worgall. (2010). Proinflammatory Phenotype and Increased Caveolin-1 in Alveolar Macrophages with Silenced CFTR mRNA. PLoS. One. 5:e11004. ISSN 1932-6203

Xu, Y., C.Tertilt, A.Krause, L.Quadri, R.Crystal, and S.Worgall. (2009). Influence of the CysticFibrosis Transmembrane Conductance Regulator on Expression of Lipid Metabolism-related Genes in Dendritic Cells. Respir Res 10:26.ISSN 1465-9921

Zaman, M.M., A.Gelrud, O.Junaidi, M.M.Regan, M.Warny, J.C.Shea, C.Kelly, B.P.O'Sullivan, and S.D.Freedman. (2004). Interleukin 8 Secretion from Monocytes of Subjects Heterozygous for the deltaF508 Cystic Fibrosis Transmembrane Conductance Regulator Gene Mutation is Altered. Clin Diagn Lab Immunol 11:819-824. ISSN 1071$412 X$ 


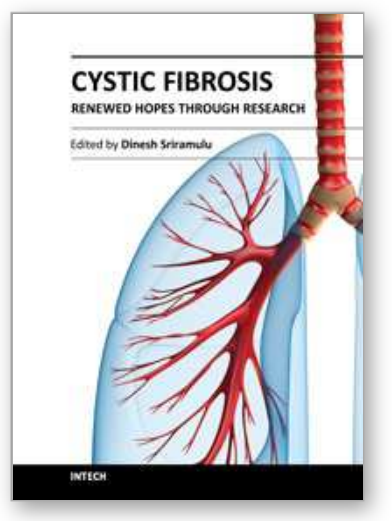

\author{
Cystic Fibrosis - Renewed Hopes Through Research \\ Edited by Dr. Dinesh Sriramulu
}

ISBN 978-953-51-0287-8

Hard cover, 550 pages

Publisher InTech

Published online 28, March, 2012

Published in print edition March, 2012

Living healthy is all one wants, but the genetics behind creation of every human is different. As a curse or human agony, some are born with congenital defects in their menu of the genome. Just one has to live with that! The complexity of cystic fibrosis condition, which is rather a slow-killer, affects various organ systems of the human body complicating further with secondary infections. That's what makes the disease so puzzling for which scientists around the world are trying to understand better and to find a cure. Though they narrowed down to a single target gene, the tentacles of the disease reach many unknown corners of the human body. Decades of scientific research in the field of chronic illnesses like this one surely increased the level of life expectancy. This book is the compilation of interesting chapters contributed by eminent interdisciplinary scientists around the world trying to make the life of cystic fibrosis patients better.

\title{
How to reference
}

In order to correctly reference this scholarly work, feel free to copy and paste the following:

Yaqin Xu and Stefan Worgall (2012). Immune Dysfunction in Cystic Fibrosis, Cystic Fibrosis - Renewed Hopes Through Research, Dr. Dinesh Sriramulu (Ed.), ISBN: 978-953-51-0287-8, InTech, Available from: http://www.intechopen.com/books/cystic-fibrosis-renewed-hopes-through-research/immune-response-incystic-fibrosis

\section{INTECH}

open science | open minds

\author{
InTech Europe \\ University Campus STeP Ri \\ Slavka Krautzeka 83/A \\ 51000 Rijeka, Croatia \\ Phone: +385 (51) 770447 \\ Fax: +385 (51) 686166 \\ www.intechopen.com
}

\author{
InTech China \\ Unit 405, Office Block, Hotel Equatorial Shanghai \\ No.65, Yan An Road (West), Shanghai, 200040, China \\ 中国上海市延安西路65号上海国际贵都大饭店办公楼 405 单元 \\ Phone: +86-21-62489820 \\ Fax: $+86-21-62489821$
}


(C) 2012 The Author(s). Licensee IntechOpen. This is an open access article distributed under the terms of the Creative Commons Attribution 3.0 License, which permits unrestricted use, distribution, and reproduction in any medium, provided the original work is properly cited. 